\title{
Attitudes of Students of the Fine Arts Educational Department towards Postgraduate Education in the Context of the Perception of Academicians
}

\author{
Armağan Konak \\ Faculty of Education, Mehmet Akif Ersoy University, Turkey
}

Copyright(C2018 by authors, all rights reserved. Authors agree that this article remains permanently open access under the terms of the Creative Commons Attribution License 4.0 International License

\begin{abstract}
This study examines the metaphors relating to the attitudes of students of the art painting education department towards post-graduate education and the concept of the "academician". A total of 81 students participated in the study who continues their education at a university in the Western Mediterranean Region of Turkey in the 2017-18 academic year. Of the students in the study group, 48 were female and 22 were male. This research refers to the mixed research design that combines both quantitative and qualitative data. In the collection of the data, the students were first asked to fill in the blanks in the sentence "An academician is like..., because...", for the purpose of identifying their metaphors towards the concept of "academician". Then, the attitude toward Postgraduate Education Scale, which was developed by Konokman and Alic1 [8] was used. The acquired metaphors were analyzed in a content analysis that is a qualitative data analysis, and the responses provided to the attitude scale were analyzed with the t-test and one-way analysis of variance, which are inferential statistics. As a result of the study, 46 metaphors were acquired for the concept of "academician", and these metaphors were gathered in 5 categories. These categories were named "guide", "information goldmine", "impressive", "fair", and "innovative". Considering the attitude toward Postgraduate Education Scale, it was determined that there was no significant difference $(.35>\mathrm{p})$ between the genders of the students. A highly significant difference was found $(.00<\mathrm{p})$ between the attitude of post-graduate education and the status of wanting to pursue post-graduate education.
\end{abstract}

Keywords Metaphor, Postgraduate Education, Art painting Education, Academician

\section{Introduction}

Education, as it is known, is a process of development that holds a primary degree of importance in society in the context of being able to capture innovation. A person, who is an individual in the society, is able to express himself/herself, exhibit their talents and this is possible through education, which demands a long process. In this respect, it is thought that the requirements of 21 st-century society are held in the forefront and that there is a need for a functional understanding of education in a practical dimension. It is observed that the advance in technology has accelerated information production and changed the purpose and definition of already existing education in hypothetical principles.

Başaran [2] defines the purpose of education as the obligations to achieve new behaviors in a manner that will be able to meet the changes in the human environment.

Varış [12], stated in a theoretical sense that education is comprehensive, timed, and multi-dimensional in terms of time and space and that it is emphasized over all kinds of experiences, including knowledge in education. It was emphasized that these experiences may be coincidental and that coincidental experiences may and may not be educational. It was added that education may be influenced by the social, cultural, political, and economic events of a society in which it is maintained.

According to Bru [4] to educate and to teach should enable the development of the capacities of children in the environment in which they live. No doubt a heavy burden is loaded upon educators who have assumed the tasks of educating and teaching.

The non-stop monitoring of innovations carried out in the field of education in the world, the strengthening of their experiences, their research, and the testing of results is expected from educators, who are aware of this responsibility today. For this reason, it is important for educators, who earn the title of a teacher after a four-year education, to be directed to postgraduate education, which offers the opportunity for research, inquiry, testing what they know, and increasing their experience. 
Individuals who become specialized through postgraduate education, which includes masters and doctoral degrees, have the opportunity to have in-depth knowledge of their professions.

Considering postgraduate education in the field of educational sciences in Turkey, it is known that in the years in which there was no postgraduate education in the field of educational sciences, the personnel in this field underwent their training abroad. The Ministry of National Education sent students to Austria, Germany, France, and the United States before the Second World War for the purpose of training expert personnel in some departments, to meet the need for teaching staff and for the other needs of the teacher training institution connected to themselves. Those who were successful in these programs generally returned to the country, having become specialized in a branch of educational sciences, and they were influential in the inclusion of educational sciences at universities and in the opening of postgraduate educational programs [10].

The opening of effective and quality postgraduate educational programs is certainly a prerequisite in the training of the teaching members who are the cornerstone of universities. Today, effective and quality postgraduate education is seen as a problem. But the problems of quality cannot be solved with the connection to formal rules and programs. It is met with problems like the inadequate number of faculty members and the inability to meet the needs of today.

According to Turgut [10], the qualitative and qualitative deficiencies encountered in the field of education originate from two primary incidents.

1. In the past, academic personnel were not trained in all specialty branches of the educational sciences. Today, there are still very few faculty members in some fields.

2. With the conversion of colleges that train teachers into universities, the secret scarcity of faculty members that exist in the field of education and the inferiority of quality is revealed in all dimensions.

Along with these problems, there are no being standardized educational programs, class content not being based on accepted principles, graduates from many fields being able to apply to one field, the failure to discuss an intelligent solution in which programs postgraduate education will open, postgraduate program entry exams differing from university to university, the social prestige and preference hierarchy of teaching as a profession being at the end can all be counted among the primary problems (Turgut, [10])

As a prerequisite in overcoming these existing problems, it is necessary to not rule out the requests of teaching candidates directed towards postgraduate education and for them to be directed towards postgraduate education, which presents the opportunity to research, inquire, be tested about what they know, and to increase their experience. For this reason, importance has been given to how teaching candidates perceive academia as a profession and their attitudes towards postgraduate education.

This study seeks the response to the underlying problems found below with the purpose of examining the metaphors relating to the attitudes of students of the art painting education department towards postgraduate education and to the concept of the "academician".

\section{Underlying Problems}

1. How can the metaphors put forward by university students with regard to the concept of "academician" be gathered under categories, in terms of shared characteristics?

2. How is the distribution of the metaphors put forward by university students with regard to the concept of "academician" based on gender?

3. Do the attitudes of university students towards postgraduate education demonstrate a significant difference based on gender?

4. Is there a significant difference between the attitudes of university students towards postgraduate education and the status of wanting to pursue postgraduate education?

\section{Materials and Methods}

\subsection{Research Model}

This study was designed based on mixed method research. Mixed method research is a research approach in which qualitative and quantitative data or techniques are combined or mixed in a single study or in a series of closely correlated studies [6]. The "phenomenology" was used from the qualitative research methods. The phenomenological design focuses on the cases of which we are aware but of which we do not possess a deep and detailed understanding [13]. A scanning model was referred to from quantitative research methods. Individuals fill out a survey in the scanning model or an interview is conducted about their attitudes, activities, thoughts, and beliefs [6].

\subsection{Study Group}

The study group of the study comprises 81 students of the Fine Arts Educational Department of the Faculty of Education of a university located in the Mediterranean Region, in the Fall semester of the 2017-2018 academic year. There are 52 females and 29 males in the study group.

\subsection{Data Tools}

A form was used as a data collection tool in which the students first are able to fill in the blanks in the sentence "An academician is like..., because...", for the purpose of 
identifying their metaphors towards the concept of "academician". Then, the Attitude toward Postgradate Education Scale, which was developed by Konokman and Alıcı [8] was used, for the purpose of identifying the attitudes of students towards postgraduate education. The Cronbach alpha reliability coefficient, regarding the integrity of the scale, was 0.939 . The findings of the analyses conducted for the purpose of determining whether there was differentiation in their attitudes, based on the departments, genders, levels of information on the subject of postgraduate education, and pursuing postgraduate education, were accepted as the evidence of the structural validity of the scale. The obtained findings revealed that the scale was a reliable and valid measurement tool for identifying the attitudes of teacher candidates with regard to postgraduate education [8].

\subsection{Data Collection and Analysis}

Metaphors were analyzed with a content analysis in the analysis of the data acquired in the study. The basic objective in the content analysis is to be able to understand the collected data and to reach correlations. The data gathered for this purpose first need to be conceptualized and later organized in a logical manner based on the concepts that emerge, and then the themes that explain the data based on this need to be identified [13]. Within the frame of this basic objective, coding, concept, and category phases were carried out, respectively, following in the content analysis.

The responses provided to the attitude scale, however, were analyzed with a t-test and one-way analysis of variance, which are inferential statistics.

\section{Findings}

The following findings were acquired as a result of the study in line with the underlying problems.

The findings are found below regarding the 1st underlying problem of the research: How can the metaphors put forward by university students with regard to the concept of "academician" be gathered under categories, in terms of shared characteristics?

Table 1 provides the metaphors that students possess with regard to the concept of an "academician" and the categorical distinction of these metaphors.

Table 1. Metaphors and their Categories that Students Possess with regard to the Concept of an "Academician"

\begin{tabular}{cccc}
\hline Categories & Metaphor & $\begin{array}{c}\text { Metaphor } \\
\text { Frequency }\end{array}$ & $\begin{array}{c}\text { Metaphor } \\
\text { Count }\end{array}$ \\
\hline Guide & Light (8), Compass (2), Lamp (1), Camera (1), Navigation (1), Candle (3), Sun (2), \\
Glasses (1), Mirror (2), Parent (1), & 22 & 10 \\
\hline \multirow{2}{*}{$\begin{array}{c}\text { Information } \\
\text { Goldmine }\end{array}$} & $\begin{array}{c}\text { Library (4), Book (11), Search Engine (1), Sack (1), Newspaper (1), Notebook (1), } \\
\text { Encyclopedia (2), Pen (3), Waterdrop (2), Tree (3), Pencil (1), Full Jar (1), Stairs (2), } \\
\text { Glass (1), Eraser (1), Pitcher (1), Umbrella (1), Mother (1), Letter Opener (1), Nature } \\
\text { (1), Doctor (1), Soil (1), Car (1), }\end{array}$ & 43 & 23 \\
\hline Impressive & Canvas (1), Statue (1), Suit (1), Abstract Painting (1), Detail (1), Jewelry (1), \\
Extraordinary (1). & 7 & 7 \\
\hline Fair & Cube (1), Scales (2). & 3 & 2 \\
\hline Innovative & Student (1), Clock (1), Water (1), White Paper (2), Snowdrop (1). & 6 & 5 \\
\hline \multicolumn{2}{c}{ TOTAL } & $\mathbf{8 1}$ & $\mathbf{4 7}$ \\
\hline
\end{tabular}

According to Table 1 above, the metaphors of the students with regard to the concept of an "Academician" have been categorically evaluated below.

Guide Category: Some expressions of students who see academicians as "guide" people are listed below.

"An academician is like a mirror. Because it reflects what you want to see."

"An academician is like a light. Because it illuminates the future."

"An academician is like a candle. Because a candle loses nothing from lighting another candle."

Information Goldmine Category: Some expressions of students who see academicians as "information goldmine" people are listed below.

"An academician is like a car. Because it takes us from one place to another."

"An academician is like a doctor. Because it overcomes, repairs knowledge."

"An academician is like a pen. Because they write information into our memories."

"An academician is like a letter opener. Because they open the road leading to knowledge."

"An academician is like a drop of water. Because it becomes a lake as it teaches."

Impressive Category: Some expressions of students who see academicians as "impressive" people are listed below.

"An academician is like a statue. Because it is still but still so majestic." 
"An academician is like an abstract painting. Because it is complex at first glance but later attains meaning."

Fair Category: Some expressions of students who see academicians as "fair" people are listed below.

"An academician is like a cube. Because all its sides are equal, fair like a cube."

"An academician is like a scale. Because it fairly measures, weighs all products that come before it."

Innovative Category: Some expressions of students who see academicians as "innovative" people are listed below.

"An academician is like a student. Because it is open to new information."

"An academician is like a white paper. Because it cultivates students with a pure heart."

"An academician is like a snowdrop. Because academicians try to rise up like the effort of a typical snowdrop to climb up over the snow."

Findings are found below regarding the 2nd underlying problem of the research: How is the distribution of the metaphors put forward by university students with regard to the concept of "academician" based on gender?

Table 2. Distribution by Gender of the Metaphors Put Forward by Middle School Students with Regard to the Concept of an Academician

\begin{tabular}{ccccccccccc}
\hline Categories & \multicolumn{2}{c}{ Guide } & \multicolumn{2}{c}{ Information Goldmine } & \multicolumn{2}{c}{ Impressive } & \multicolumn{2}{c}{ Fair } & \multicolumn{2}{c}{ Innovative } \\
\hline Gender & $\mathrm{n}$ & $\%$ & $\mathrm{n}$ & $\%$ & $\mathrm{n}$ & $\%$ & $\mathrm{n}$ & $\%$ & $\mathrm{n}$ & $\%$ \\
\hline Female & 16 & 72.7 & 26 & 60.5 & 6 & 85.7 & 1 & 33.3 & 3 & 50 \\
\hline Male & 6 & 27.3 & 17 & 39.5 & 1 & 14.3 & 2 & 66.7 & 3 & 50 \\
\hline Total & 22 & 100 & 43 & 100 & 7 & 100 & 3 & 100 & 6 & 100 \\
\hline
\end{tabular}

Considering the distribution of the metaphors of the students based on gender with regard to the concept of an "academician", it is seen that there were 19 females and 6 males in the "guide" category, 26 females and 17 males in the "information goldmine" category, 6 females and 1 male in the "impressive" category, 1 female and 2 males in the "fair" category, and 3 females and 3 males in the "innovative" category.

The Findings are found below regarding the 3rd underlying problem of the research: Do the attitudes of university students towards postgraduate education demonstrate a significant difference based on gender?

Table 3 shows the t-test results based on gender for the points on the scale of the attitudes of the students based on post-graduate education.

Table 3. The T-Test Results Based on Gender on the Points of the Scale of the Attitudes on Postgraduate Education

\begin{tabular}{ccccccc}
\hline Gender & $\mathbf{N}$ & $\overline{\mathbf{x}}$ & $\mathbf{S}$ & $\mathbf{s d}$ & $\mathbf{t}$ & $\mathbf{p}$ \\
\hline Female & 52 & 107.18 & 12.09 & 79 & .93 & .35 \\
Male & 29 & 104.51 & 13.27 & 64.59 & & \\
\hline
\end{tabular}

$\mathrm{p}<.01$

The attitudes of the students towards post-graduate education did not show a significant difference based on gender $\left[\mathrm{t}_{(160)}=.93, \mathrm{p}>.01\right]$. The attitudes of male students towards postgraduate education $(\bar{X}=104.5)$ and the attitudes of female students $(\bar{X}=107.51)$ were very close to one another.

The findings are found below regarding the 4th underlying problem of the research: Is there a significant difference between the attitudes of university students towards postgraduate education and the status of wanting to pursue postgraduate education?

Table 4 reports the ANOVA results based on the status of students wanting to pursue postgraduate education and their attitudes towards postgraduate education.

Table 4. ANOVA Results Based on the Status of Students Wishing to Pursue Postgraduate Education and their Attitudes Towards Postgraduate Education

\begin{tabular}{ccccccc}
\hline Source of Variance & Sum of Squares & sd & Average of Squares & F & p & Significant Difference \\
\hline Intergroup & 2876.04 & 2 & 1438.02 & 11.47 & .00 & Yes-No \\
Intragroup & 9779.16 & 78 & 125.37 & & Yes-I Do Not Know \\
Total & 12655,21 & 80 & & & \\
\hline $\mathrm{p}<.01$ & & & & &
\end{tabular}


According to the results of the analysis, it is seen that there was a significant difference between the attitudes of students towards postgraduate education and their status of wishing to pursue postgraduate education $\left[\mathrm{F}_{(2-78)}=11.47\right.$, $\mathrm{p}<.01]$. In other words, the attitudes of students towards postgraduate education vary significantly depending on whether they wish to pursue postgraduate education. Table 5 below provides the results of the Scheffe test conducted for the purpose of finding among which groups there are differences between the responses on whether or not they wish to pursue post-graduate education.

Table 5. Scheffe Test Results of the Desires of Students to Pursue Postgraduate Education and Their Attitudes towards Postgraduate Education

\begin{tabular}{cccc}
\hline & & \multicolumn{2}{c}{ Alpha=0.01 } \\
\cline { 3 - 4 } Postgraduate Education & N & 1 & 2 \\
\hline No & 6 & 96.16 & \\
I do not know & 31 & 100.38 & 111.47 \\
Yes & 44 & & \\
\hline
\end{tabular}

According to the results of the Scheffe test conducted for the purpose of finding among which groups there are differences between the responses on whether or not they wish to pursue post-graduate education, the attitudes towards postgraduate education of the students who provided a Yes response $(\bar{X}=111.47)$ were more positive than the students who provided a No response $(\bar{X}=96.16)$ and an I Don't Know response $(\bar{X}=100.38)$.

\section{Conclusions}

There are some perceptions about the concept of "academician" with regard to the thoughts that university students reached as a result of their academic educations and experiences. It is thought that the fact that the perceptions towards academia are positive and that the importance of postgraduate education is emphasized carries importance in the name of being open to new information and the renewed production of this information.

For this reason, this study, which aimed to reveal the attitudes of university students towards postgraduate education, referred to the metaphors of students towards academicians to support the attitudes. It is seen that there are quite a few metaphors that express the importance and value of academia.

As a result of the metaphor analysis, it was seen that students developed 46 metaphors towards the concept of an "academician" and these metaphors were gathered into 5 categories. In line with these categories, it was determined that students perceived academia as a "guide", "information goldmine", "impressive", "fair", and "innovative".

Considering the results of the Attitudes towards
Postgraduate Education Scale used in the research, it was determined that there was no significant difference between the genders and the opinions towards the postgraduate education of the students. However, there was a highly significant difference $(.00<\mathrm{p})$ between their attitudes towards postgraduate education and their status of wishing to pursue postgraduate education. The conclusion was reached that the attitudes of students wishing to pursue postgraduate education were more positive compared with the students who did not wish to do so or were undecided.

Considering other research conducted in this field, it was seen that there were results that possess findings that support the conclusion of the study.

As a result of the study that Ataman [1] carried out with 115 music teacher candidates entitled "Examination of the Attitudes of Music Teacher candidates towards Post-Graduate Education (The Example of Balıkesir University)", it was determined that music teacher candidates generally hold positive attitudes towards postgraduate education. Moreover, contrary to the results of this study, Ataman [1] found a significant difference between attitudes towards post-graduate education with gender in that study.

As a result of the qualitative study entitled "Opinions Relating to Post-Graduate Education of Classroom Teacher Candidates" that was carried out by Samanc1, Özdemir, and Yilar [9], it was interpreted that there were positive thoughts towards postgraduate education.

The study entitled "Metaphoric Perceptions Regarding Post-Graduate Education of Teacher Candidates" that was carried out in 2016 by Bozpolat [3] obtained metaphors for post-graduate education. The categories of "Value" and "Guide" from these metaphors were similar to the categories obtained in this study.

The results of the study entitled "Attitudes for Post-Graduate Education of Classroom Teacher Candidates (The United States Example of Classroom Teaching of Frrat, Erzincan, and İnönü University)" of Ünal and Ilter [11] showed that students have positive attitudes towards postgraduate education. But unlike this study, a significant difference was found between the genders and the attitudes towards postgraduate education of the students.

Similiar to the results of this study, the research entitled "Examination of the Attitudes Towards Postgraduate Education of Primary School Teachers" by Ilhan, Öner, and Yilmaz [7] did not find a significant difference between the attitudes towards postgraduate education and the genders of students.

\section{Recommendations}

The following recommendations can be made with regard to the results of this research. 
1. Depending on the attitudes of university students towards postgraduate education being positive, students can be informed about postgraduate education and encouraged to pursue postgraduate education. Thus, those researching the educational system, those questioning information, and those educators producing new information may be gained.

2. In this study, with regard to there being quite a lot of metaphors that express the importance and value of academia, students can be provided with information about the academic profession and can be directed towards academia in the name of resolving to a degree the academician gap in Turkey that was acquired in the Literature review.

\section{REFERENCES}

[1] Ataman, Ö. G. (2014). Müzik Öğretmeni adaylarının Lisansüstü Eğitime Yönelik Tutumlarının İncelenmesi (Balıkesir Üniversitesi Örneği), Akademik Bakış Dergisi. Say1 43 Mayıs-Haziran.

[2] Başaran, İ. E. (1978). Eğitime Giriş. Ankara: Kadığlu Matbaasi.

[3] Bozpolat, E. (2016), Öğretmen Adaylarının Lisansüstü Eğitime İlişkin Metaforik Algıları. İlköğretim Online Dergisi, 15(4):1114-1130.

[4] Bru, M. (2006). Les Méthodes En Pédagogie. Paris: Presses
Universitaire De France.

[5] Büyüköztürk, Ş. (2007). Sosyal Bilimler İçin Veri Analizi El Kitabı. Ankara: Pegem Akademi Yayınları.

[6] Christensen, L. B., Johnson, B. R., Turner, L. A., (2015). Araştırma Yöntemleri Desen ve Analiz. Ankara:Anı Yayıncilik.

[7] Ilhan, M., Öner, S. M., and Yılmaz, F. (2012). İlköğretim Öğretmen Adaylarının Lisansüstü Eğitime Yönelik Tutumlarının İncelenmesi (Dicle Üniversitesi Örneği). Mehmet Akif Ersoy Üniversitesi Eğitim Fakültesi Dergisi. Say1 23, 22-42.

[8] Konokman, G. Y. and Alıc1, D., (2014). Lisansüstü Eğitime İlişkin Tutum Ölçeği: Güvenirlik ve Geçerlik Çalışması. International Online Journal of Educational Sciences, 6 (1), 112-129.

[9] Samancı, O., Özdemir, R., and Yılar, R., Sınıf Öğretmeni Adaylarının Lisansüstü Eğitim ile İlgili Görüşleri, e-Kafkas Eğitim Araştırmaları Dergisi. Cilt 3, Sayı 1.

[10] Turgut, M. F. (2014). Eğitimde Lisansüstü Eğitim. Hacettepe Üniversitesi Eğitim Fakültesi Dergisi. Cilt 2. Say1 2.

[11] Ünal, Ç. \& Ilter, I., (2010). Sınıf Öğretmeni Adaylarının Lisansüstü Eğitime Olan Tutumları (Frrat, Erzincan ve İnönü Üniversitesi Sınıf Öğretmenliği ABD Örneği). Atatürk Üniversitesi Sosyal Bilimler Enstitüsü Dergisi. 14 (2):1-18.

[12] Varış, F. (1991). Eğitim Bilimine Giriş. Ankara: Ankara Üniversitesi Yayınlar1.

[13] Yıldırım, A., Şimșek, H., (2008). Sosyal Bilimlerde Nitel Araştırma Yöntemleri. Ankara: Seçkin Yayıncılık. 